\title{
Effects of Defined Mixtures of Persistent Organic Pollutants (POPs) on Pre-lethal Cytotoxicity in the Human A-498 Kidney Cell Line In Vitro
}

\author{
Mazia Amber ${ }^{1}\left[\right.$ Yuling Xie $^{1} \cdot$ Hanne Friis Berntsen ${ }^{2,3} \cdot$ Karin Elizabeth Zimmer $^{4} \cdot$ Erik Ropstad $^{2}$. \\ Steven Verhaegen ${ }^{2}$ (D) Lisa Connolly ${ }^{1}$ (I)
}

Received: 13 February 2021 / Revised: 21 April 2021 / Accepted: 23 April 2021 / Published online: 10 May 2021

(c) The Author(s) 2021

\begin{abstract}
A total mixture of 29 persistent organic pollutants (POPs) modelled from Scandinavian blood concentrations was used to expose human A-498 kidney cells for $24 \mathrm{~h}$ over a concentration range spanning below to above blood level (1/10x, 1x, 50x, 100x, 500x). Its constituent submixtures (PFAA, $\mathrm{Br}, \mathrm{Cl}$ ) and co-mixtures (PFAA $+\mathrm{Br}, \mathrm{PFAA}+\mathrm{Cl}, \mathrm{Br}+\mathrm{Cl}$ ) were also tested. Valinomycin $(12 \mu \mathrm{M})$ was used as a cytotoxic comparative compound. Cell number $(\mathrm{CN})$, nuclear area (NA), nuclear intensity (NI), mitochondrial membrane potential (MMP), and mitochondrial mass (MM) were assessed using high content analysis (HCA). Only the co-mixtures (PFAA $+\mathrm{Cl}, \mathrm{PFAA}+\mathrm{Br}$ ) at 50x and 50x, 500x decreased $\mathrm{CN}$, respectively. NI was increased by the total mixture at 500x and $\mathrm{Cl}$ mixture at all concentrations tested. MMP was increased by the total mixture at 100x and $500 x, \mathrm{PFAA}$ at $1 \mathrm{x}, \mathrm{Br}+\mathrm{Cl}$ and PFAA $+\mathrm{Cl}$ at 100x and 500x, respectively. MM was decreased by the total mixture at 500x. In contrast, valinomycin decreased $\mathrm{CN}$ and surviving cells showed a decrease in MMP and an increase in MM. In conclusion, POP exposure altered mitochondrial metabolism and induced cell death via an alternative mechanism to valinomycin. Only specific combinations of individual chemical classes, but not the total mixture, affected cell number.
\end{abstract}

Keywords Polychlorinated biphenyls · Organochlorinated pesticides · Brominated flame retardants · Perfluorinated alkylating agents $\cdot$ Cytotoxicity $\cdot$ High content analysis

\section{Introduction}

Persistent organic pollutants (POPs) are chemicals that persist in the environment for decades and can bioaccumulate or biomagnify in living organisms. POPs tend to accumulate in the metabolic organs including kidneys and liver which may lead to histological alterations in these organs (Tashla et al.

Lisa Connolly

1.connolly@qub.ac.uk

1 Institute for Global Food Security, School of Biological Sciences, Queen's University Belfast, Belfast BT9 5DL, Northern Ireland, UK

2 Department of Production Animal Clinical Sciences, Faculty of Veterinary Medicine, Norwegian University of Life Sciences, P.O. Box 5003 NMBU, 1432 Ås, Norway

3 National Institute of Occupational Health, P.O. Box 5330 Majortuen, 0304 Oslo, Norway

4 Department of Preclinical Sciences and Pathology, Faculty of Veterinary Medicine, Norwegian University of Life Sciences, P.O. Box 369 5003, 1432 Ås, Norway
2018). We have previously shown that POP mixtures can have detrimental effects on the health of liver cells (Wilson et al. 2016). The kidney, another organ, which plays a major role in excretion, may also be a target of cytotoxicity for these compounds. Continuous exposure to POPs may lead to end-stage nephropathy in addition to other diseases such as diabetes and cardiovascular illnesses (Grice et al. 2017).

Since POPs are widely distributed in geographical regions of the world, various animal studies have highlighted the negative impact of POPs on wildlife. Wild arctic foxes exposed to a cocktail of POPs including organochlorine pesticides (OCPs) and polychlorinated biphenyls (PCBs) show signs of kidney and liver damage (Pizzorno 2015). PCBs and OCPs have also been found to trigger glomerular lesions in Baltic seals and dilation of glomerular capillaries and mesangial deposits in fish (Bergman et al. 2001; Koponen et al. 2001).

Perfluorinated alkyl agents (PFAAs) are a new class of POPs associated with reduction in kidney function and increased uric acid levels in humans (Kataria et al. 2015). Human mortality studies have shown an association between 
kidney cancers and occupational exposure to PFOA in the US population (Leonard et al. 2008; Steenland and Woskie 2012). A large cohort study on adults consuming drinking water from near a chemical plant in the US and workers directly exposed to PFAAs show positive association between cumulative perfluorooctanoic acid (PFOA) exposure and kidney cancer (Barry et al. 2013). These studies have highlighted the harmful effects of individual POPs particularly PFAAs on excretory organs including kidneys. However, in real-life situations both animals and humans are exposed to a mixture of chemicals that can interact to enhance or suppress the overall health effect. Therefore, analysing exposure mixtures based on real-life human concentrations is a more realistic approach for assessing potential health effects.

In the current study, we have used defined POP mixtures, modelled on levels found in the blood of the Scandinavian population. A total of 29 POPs were selected as described by Berntsen et al. (2017), based on their prominence in human blood, breast milk and/or food according to a literature review on levels in the Scandinavian population (Haug et al. 2010; Knutsen et al. 2008; Polder et al. 2008, 2009; Van Oostdam et al. 2004). This total mixture contained three chemical classes of POPs, i.e. chlorinated, brominated, and perfluorinated chemicals. In addition, submixtures were created representing each individual class: a chlorinated $(\mathrm{Cl})$ mixture, brominated $(\mathrm{Br})$ mixture, and a perfluorinated (PFAA) mixture, respectively. Finally, co-mixtures representing possible binary combinations of each class were also generated: chlorinated + brominated $(\mathrm{Cl}+\mathrm{Br})$ mixture, perfluorinated + brominated $(\mathrm{PFAA}+\mathrm{Br})$ mixture and perfluorinated + chlorinated $(\mathrm{PFAA}+\mathrm{Cl})$ mixture. A summary of these POP mixtures can be found in Table 1. Further details on the POP mixture composition and selection criteria can be found in Berntsen et al. (2017). The total mixture, sub-mixtures and co-mixtures were tested in a concentration dependent manner over a range above and below human blood levels (1/10x to 500x).

POP mixtures are known to have cytotoxic effects on the excretory organs (Nicole 2013). Traditional cytotoxicity assays are sometimes insensitive to the cellular response towards chemicals. Therefore, sensitive pre-lethal mechanistic cellular assays are used to determine endpoint specific chemical responses using cell lines (Xu et al. 2004). In the current study, we have used valinomycin as a comparative chemical for the induction of toxicity via effects on cellular nuclear and mitochondrial parameters (Abdalah et al. 2006; Abraham et al. 2008).

High content analysis (HCA) is a platform used to study cellular parameters where subtle or pre-lethal cytotoxic effects of human relevant POP mixtures can be analysed. Multiple cellular health endpoints can be measured following exposure to POPs in a single experimental setting
(Anderl et al. 2009). This provides insights into the health status of cells, including gross cytotoxicity and subtle prelethal cytotoxic effects, which can indicate potential cellular function impairment. A decrease in cell number is an indicator of gross cytotoxicity. The changes in nuclear area upon exposure to chemicals may indicate initiation of the cell death pathways. A decrease in nuclear area and condensation of chromatin indicates that a cell might be undergoing apoptotic cell death (Elmore 2007). Necrosis is an alternative cell death pathway whereby both the nuclear and cell area increase (Galluzzi et al. 2018). Subtle indicators of cell health include changes in mitochondrial membrane potential and mitochondrial mass (Youle and van der Bliek 2012). This in-depth analysis using HCA has advantages over gross cytotoxicity assays, which only indicate that a cell has died, because some detrimental health effects may still occur through pre-lethal cytotoxicity, even if a cell survives exposure.

In the present study, we focused on determining the effects of complex mixtures of POPs on the A-498 human epithelial kidney cell line. A-498 is a classic cell line belonging to the NCI-60 panel, used in renal toxicity studies and cancer research (Brodaczewska et al. 2016; Adam et al. 2006). Cells were exposed to the mixture of POPs, and cytotoxic effects were measured using HCA.

\section{Materials and Methods}

\section{Chemicals}

Cell culture reagents were supplied by Life Technologies (Paisley, UK). MitoTracker ${ }^{\circledR}$ Orange CMTMRos was provided by Thermo Scientific UK. A stock solution (1 mM) was prepared by adding $117 \mu \mathrm{l}$ of anhydrous DMSO to $50 \mu \mathrm{g}$ dye and stored at $-20^{\circ} \mathrm{C}$. Working stocks of $100 \mathrm{nM}$ were prepared in assay media on the day of use. Hoechst nuclear stain 33,342 solution $(20 \mathrm{mM})$ was also provided by Thermo Scientific UK. An intermediate stock of $10 \mathrm{mM}$ Hoechst 33,342 was prepared in PBS and stored at $4{ }^{\circ} \mathrm{C}$. Working stock at final concentration of $1.6 \mu \mathrm{M}$ was prepared on the day of staining.

Formalin solution neutral buffered (10\%) was supplied by Sigma-Aldrich (Dorset, UK). All other reagents were standard laboratory grade.

\section{Persistent Organic Pollutant Mixtures}

Mixtures of the test POPs were designed and prepared by the Norwegian University of Life Sciences, Oslo (Berntsen et al. 2017), and concentrations of relevant POPs were based on levels measured in human blood, according to recent studies of the Scandinavian population. The seven mixtures tested 


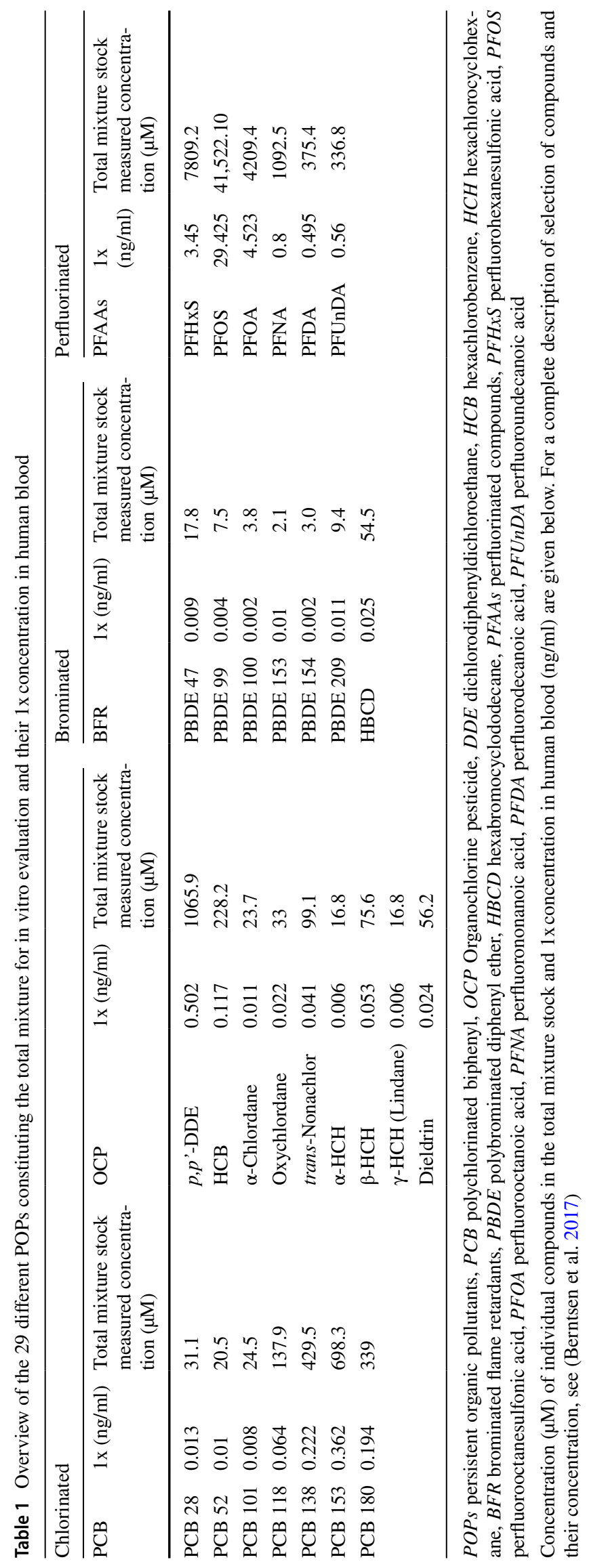


include: a total mixture containing all the compounds, three submixtures (including a perfluorinated mixture (PFAA), a brominated mixture $(\mathrm{Br})$ and a chlorinated mixture $(\mathrm{Cl})$, and three co-mixtures (including a perfluorinated and brominated mixture (PFAA $+\mathrm{Br}$ ), a perfluorinated and chlorinated mixture (PFAA $+\mathrm{Cl})$, and a brominated and chlorinated mixture $(\mathrm{Br}$ and $\mathrm{Cl})$. Table 1 provides a brief overview of 29 different POPs constituting the total mixture used. A complete description of selection of compounds and their individual concentrations can be found in (Berntsen et al. 2017). Stocks were created in DMSO at concentrations equivalent to $1,000,000 x$ human blood concentrations for the total mixture, $\mathrm{Cl}$ mixture, and all combinations with the $\mathrm{Cl}$ mixture. The PFAA mixture, the Br mixture, and the PFAA + Br mixture stocks were 10 times more concentrated, and equivalent to $10,000,000 x$ human blood concentrations. Stocks were stored at $-20{ }^{\circ} \mathrm{C}$. For the exposure studies described below, stocks were serially diluted into medium and tested at final concentrations equivalent to $1 / 10 x, 1 x, 50 x, 100 x$, $500 x$ relative to blood levels. Final DMSO concentration was $0.2 \%$ and was kept constant in all dilutions tested.

\section{Cell Culture and Treatment}

The human kidney A-498 cell line (ATCC® HTB-44TM) was obtained from the American Type Culture Collection (ATCC) and routinely cultured in a humidified atmosphere of $5 \% \mathrm{CO}_{2}$ at $37{ }^{\circ} \mathrm{C}$. Cells were grown in $75 \mathrm{~cm}^{2}$ flasks in MEM media supplemented with $10 \%$ FBS, 2 mM L-glutamine and $1 \mathrm{mM}$ sodium pyruvate. TrypLE ${ }^{\mathrm{TM}}$ Express was used to disperse cells from flasks.

Cells were seeded at a density of $6 \times 10^{4}$ cells $/ \mathrm{ml}$ into Corning $^{\mathrm{TM}}$ BioCoat ${ }^{\mathrm{TM}}$ Collagen I Multiwell Plates and allowed to attach for $24 \mathrm{~h}$. The cells were then exposed to the total mixture and 6 submixtures at 5 concentrations (1/10x, 1x, 50x, 100x, 500x blood levels) and incubated for $24 \mathrm{~h}$. Final concentration of DMSO was kept constant at $0.2 \%$. Valinomycin $(12 \mu \mathrm{M})$ was used as a cytotoxic comparative compound and a solvent negative control 0.2\% (v:v) DMSO in media was also included.

\section{High Content Analysis}

Cellomics ${ }^{\circledR}$ High Content Screening reagent series multiparameter cytotoxicity dyes were prepared by following the manufacturer's instructions and used to measure assay parameters including mitochondrial membrane potential (MMP), mitochondrial mass (MM), cell number (CN), nuclear area (NA) and nuclear intensity (NI). MitoTracker ${ }^{\circledR}$ Orange CMTMRos was used as a mitochondrial membrane potential dye evaluate parameters of mitochondrial function: MMP and MM. A stock solution of $1 \mathrm{mM}$ was prepared following manufacturer's instruction. Following 24 h exposure to the POP mixtures, assay media was removed and cells were exposed to $100 \mathrm{nM}$ of MitoTracker ${ }^{\circledR}$ Orange CMTMRos. The plates were protected from light and incubated for $30 \mathrm{~min}$ at $37^{\circ} \mathrm{C}$. Cells were washed with $200 \mu \mathrm{l}$ of assay media and with PBS following 5 min incubation in assay media at $37{ }^{\circ} \mathrm{C}$. Cells were then fixed using $2 \%$ formalin solution for $15 \mathrm{~min}$ at room temperature (RT) and washed with $200 \mu \mathrm{l}$ PBS. To measure parameters reflecting nuclear morphology: CN, NI and NA, Hoechst 33,342 dye (at a final concentration of $1.6 \mu \mathrm{M}$ ) was added to each well and incubated at RT for $20 \mathrm{~min}$. Cells were then washed once with PBS; $100 \mu \mathrm{l}$ PBS was added to each well and cells evaluated on CellInsight ${ }^{\mathrm{TM}}$ NXT High Content Screening (HCS) Platform. Cytotoxicity of the test compounds was measured as $\% \mathrm{CN}$ and compared to the solvent control (0.2\% DMSO), set to a relative response of $100 \%$. Valinomycin $(12 \mu \mathrm{M})$ was used as a positive control for the induction of pre-lethal cytotoxicity in the A-498 cell line.

Data were captured at 20x objective magnification in the selected excitation and emission wave-lengths for Hoechst 33,342 dye (Ex/Em 350/461 nm), and MitoTracker ${ }^{\circledR}$ Orange CMTMRos (Ex/Em 554/ 576 nm). Twenty five field view images were acquired in each well to examine each parameter.

\section{Statistical Analysis}

Three independent exposures were performed, each in triplicate wells. Data were analysed using Graphpad Prism and Microsoft Excel, version 5.01 (San Diego, CA). Values are expressed as mean \pm standard error of mean (SEM) of triplicate, independent exposures. Data are expressed in percentage of solvent control (0.2\% DMSO) for each parameter. Analysis was done using one-way analysis of variance (ANOVA) followed by Dunnett's multiple comparisons test. Mean concentrations were tested for significant difference at $95 \%$ confidence level. A $p$ value of $<0.05$ was considered statistically significant, $p \leq 0.05(*), \leq 0.01(* *)$ and $\leq 0.001$ $(* * *)$.

\section{Results}

\section{Effects on Cell Number}

Valinomycin exposure concentration in the A-498 kidney cell line was optimised following $24 \mathrm{~h}$ exposure to $6 \mu \mathrm{M}$, $12 \mu \mathrm{M}$ and $15 \mu \mathrm{M}$. Statistically significant reductions in cell number $(\mathrm{CN})$ of 22,57 , and $85 \%$, respectively, were observed when compared to the solvent control (SC) at $100 \%$ (Fig. 1). Based on this $12 \mu \mathrm{M}$ valinomycin was selected as an optimum concentration for the induction of pre-lethal toxicity and this concentration was used as a 


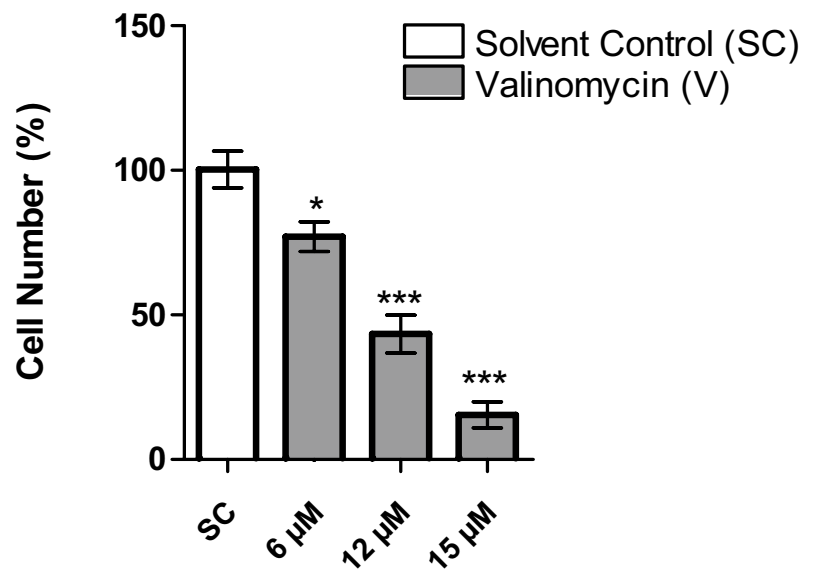

Concentration $(\mu \mathrm{M})$

Fig. 1 Changes in cell number $(\mathrm{CN})$ assessed by high content analysis in the A-498 human kidney cell line following 24-h exposure to $6 \mu \mathrm{M}, 12 \mu \mathrm{M}$ and $15 \mu \mathrm{M}$ positive control valinomycin (V). DMSO $(0.2 \%)$ was used as solvent control (SC). $n=3$; Significant differences from the SC are indicated with $*=p \leq 0.05$, ** $=p \leq 0.01$, $* * *=p \leq 0.001$

positive control throughout the study. No significant changes in $\mathrm{CN}$ were observed when cells were exposed to the total mixture (Fig. 2a) or to the individual $\mathrm{Cl}, \mathrm{Br}$ and PFAA mixtures (Fig. 2b). In contrast, there was a significant decrease in $\mathrm{CN}$ for the PFAA $+\mathrm{Cl} 50 \times$ and the PFAA $+\mathrm{Br} 50 \mathrm{x}$ and 500x exposure concentrations when compared with the SC (Fig. 2c).

\section{Effects on Nuclear Parameters}

The Hoechst 33,342 stained nuclei were assessed by HCA to quantify changes in nuclear area (NA) following $24 \mathrm{~h}$ exposure to the POP mixtures. No significant changes in NA were observed for any of the mixtures tested except for the total mixture, which decreased the NA slightly at 500x, the highest tested human relevant concentration (Fig. 3a). No significant changes in NA were observed for the other mixtures tested.

Nuclear intensity (NI) is another cellular health marker used to assess the overall health of the nuclei. No statistically significant changes in NI were observed following exposure to valinomycin at $12 \mu \mathrm{M}$. NI was significantly increased by the total mixture 500x and $\mathrm{Cl}$ mixture at all concentrations tested (Fig. 3b and c, respectively). No significant changes in NI were observed for the other mixtures tested.

\section{Effects on Mitochondrial Parameters}

Mitochondrial membrane potential (MMP) is measured as intensity of fluorescence. A significant decrease in MMP

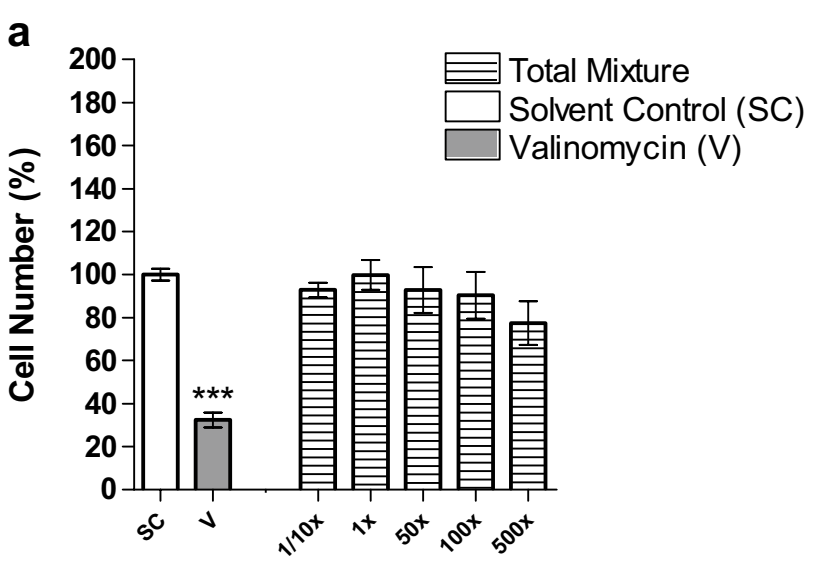

Concentration (x Blood Levels)
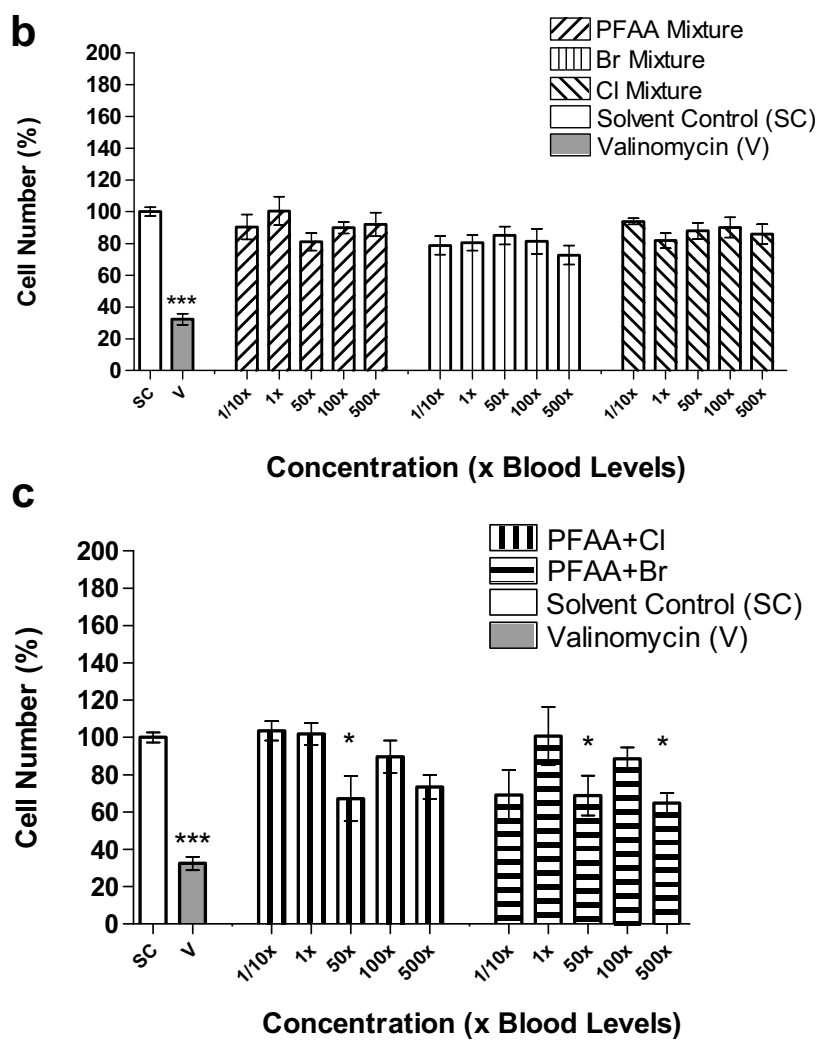

Fig. 2 Cell number (CN) assessed by HCA in the A-498 human kidney cell line following $24 \mathrm{~h}$ exposure to total mixture a; PFAA, $\mathrm{Br}$ and $\mathrm{Cl}$ mix $\mathbf{b}$; and PFAA $+\mathrm{Cl}$ and PFAA $+\mathrm{Br}$ mixtures $\mathbf{c}$ DMSO $(0.2 \%)$ was used as solvent control (SC) and $12 \mu \mathrm{M}$ valinomycin $(\mathrm{V})$ was used as a comparative cytotoxic compound. $n=3$; Significant differences from the SC are indicated with $*=p \leq 0.05$, ** $=p \leq 0.01$, $* * *=p \leq 0.001$

was observed in the cells exposed to $12 \mu \mathrm{M}$ valinomycin (Fig. 4a and b) when compared to the solvent control (Fig. 4a and b). Changes in MMP following exposure to different concentrations of POPs were evaluated. MMP was significantly increased by the total mixture 100 and 500x blood 


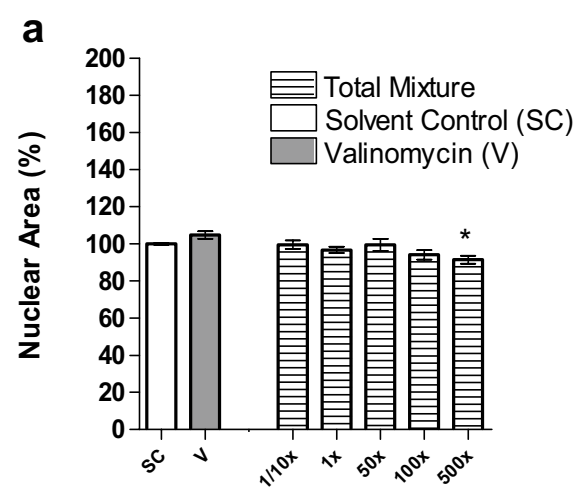

Concentration (x Blood Levels) b

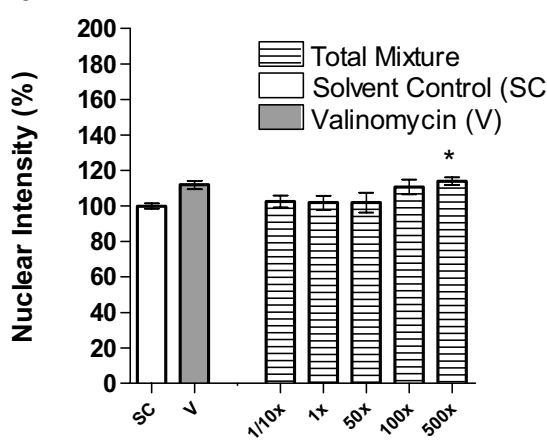

Concentration (x Blood Levels)

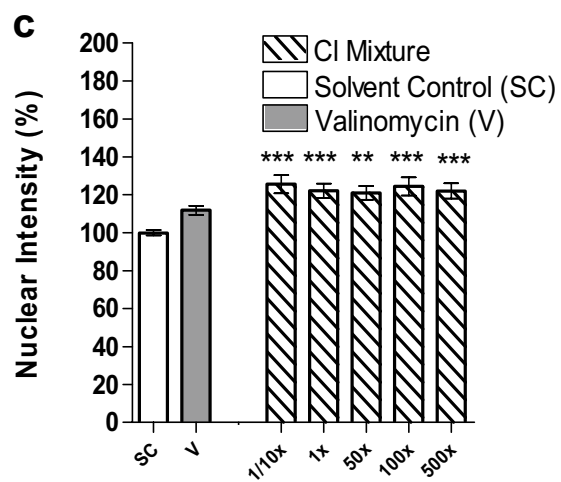

Concentration (x Blood Levels)
Fig. 3 Nuclear parameter changes assessed in the A-498 cell line by HCA following 24-h exposure to POP mixtures. a) Nuclear Area (NA) changes following exposure to total mixture, b) Nuclear Intensity (NI) changes following exposure to the total mixture and c)
Nuclear Intensity (NI) changes following exposure to the $\mathrm{Cl}$ mixture. DMSO $(0.2 \%)$ was used as solvent control (SC) and valinomy$\operatorname{cin}(12 \mu \mathrm{M})(\mathrm{V})$ was used as cytotoxic comparative compound. $n=3$; $*=p \leq 0.05, * *=p \leq 0.01, * * *=p \leq 0.001$ levels (Fig. 4a) and PFAA mixture 1x, $\mathrm{Br}+\mathrm{Cl}$ mixture 100x, PFAA $+\mathrm{Cl}$ mixture 500x (Fig. 4b). No significant changes in MMP were observed for the other mixtures tested.

Changes in mitochondrial mass (MM) can also be used to quantify pre-lethal cytotoxicity using HCA. Figure 5 presents HCA images obtained for MM and shows that in comparison with the solvent control (Fig. 5a), a significant increase in MM was observed in the cells exposed to $12 \mu \mathrm{M}$ valinomycin (Fig. 5b). No significant change in the MM was induced by the total mixture at $1 \mathrm{x}$ blood levels, whereas it was significantly decreased after exposure to a concentration of 500x blood levels (Fig. 5d). No significant changes in MM were observed in all the other mixtures tested. Figure 6 graphically presents the full concentration range of total mixture exposure results for MM.

\section{Discussion}

The effect of POP mixtures at human relevant exposure concentrations on A-498 human kidney cells was evaluated. In the first instance, we evaluated cytotoxic effects by quantifying cell number $(\mathrm{CN})$ via Hoechst-stained nuclei in a high content analysis (HCA) approach. Neither the total mixture, nor the mixtures representing the major constituent classes ( $\mathrm{Cl}, \mathrm{Br}, \mathrm{PFAA})$ had any effect on the $\mathrm{CN}$ when tested separately. However, the PFAA $+\mathrm{Cl}$ and $\mathrm{PFAA}+\mathrm{Br}$ combinations negatively affected $\mathrm{CN}$. These decreases were still only about $50 \%$ of the magnitude observed with valinomycin.

Cell death is often accompanied by changes in nuclear morphology. Apoptosis is associated with nuclear shrinkage and fragmentation, resulting in a decrease in nuclear area (NA) (Bortner and Cidlowski 2002). Chromatin condensation during the process results in more concentrated staining with DNA-binding fluorescent probes, giving rise to increased nuclear intensity (NI). Necrosis often gives rise to enlarged nuclei with flocculated chromatin, resulting in increased NA (Buchser et al. 2004). Our HCA approach allowed for simultaneous detection of changes in nuclear parameters such as NA and NI. A slight but statistically significant decrease in NA and increase in NI were observed at the highest exposure concentration of the total mixture. A statistically significant increase in NI was observed for the $\mathrm{Cl}$ mixture at all the exposure concentrations.

Taken these observations together, exposure to the total mixture has no significant effect on cell viability, except at a concentration corresponding to 500x the concentrations in human blood. This low cytotoxicity when $\mathrm{CN}$ is taken in consideration is in agreement with previous observations with the same mixture. Indeed, in a U-2 OS cell line expressing a fluorescently tagged human androgen receptor, no effect on $\mathrm{CN}$ was noted at concentrations up to 500x after $6 \mathrm{~h}$ (McComb et al. 2019). In HepG2 liver cells no effect on $\mathrm{CN}$ was seen for concentrations up to 1000x (Wilson et al. 2016). In pGIP/neo: STC-1 enteroendocrine cells a reduction is seen with total mixture, submixtures, and their combinations. However, an effect on $\mathrm{CN}$ has been noted with the $\mathrm{Cl}$ mixture alone at concentrations starting at $1 \mathrm{x}(\mathrm{McComb}$ et al. 2019). This indicates that the cytotoxic effects of individual classes of compounds can be masked within the total mixture by combinatorial or antagonist effects. Overall, the effect of human relevant POP mixtures on direct cellular cytotoxicity as monitored by nuclear changes seems limited. Only when the perfluorinated compounds are combined with either the chlorinated or the brominated compounds is a 
Fig. 4 Mitochondrial Membrane Potential (MMP) assessed in the A-498 cell line by HCA following $24 \mathrm{~h}$ exposure to a total mixture and $\mathbf{b}$ the $\mathrm{PFAA}, \mathrm{Br}+\mathrm{Cl}$, and $\mathrm{PFAA}+\mathrm{Cl}$ mixtures. DMSO (0.2\%) was used as solvent control (SC) and valinomycin $(12 \mu \mathrm{M})$ was used as cytotoxic comparative compound. $n=3 ; *=p \leq 0.05$, $* *=p \leq 0.01, * * *=p \leq 0.001$ a

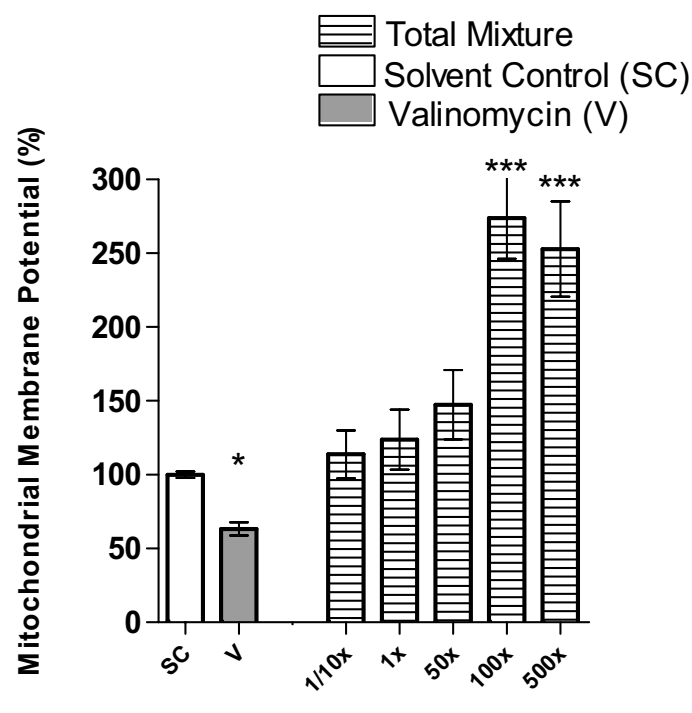

Concentration (x Blood Levels)

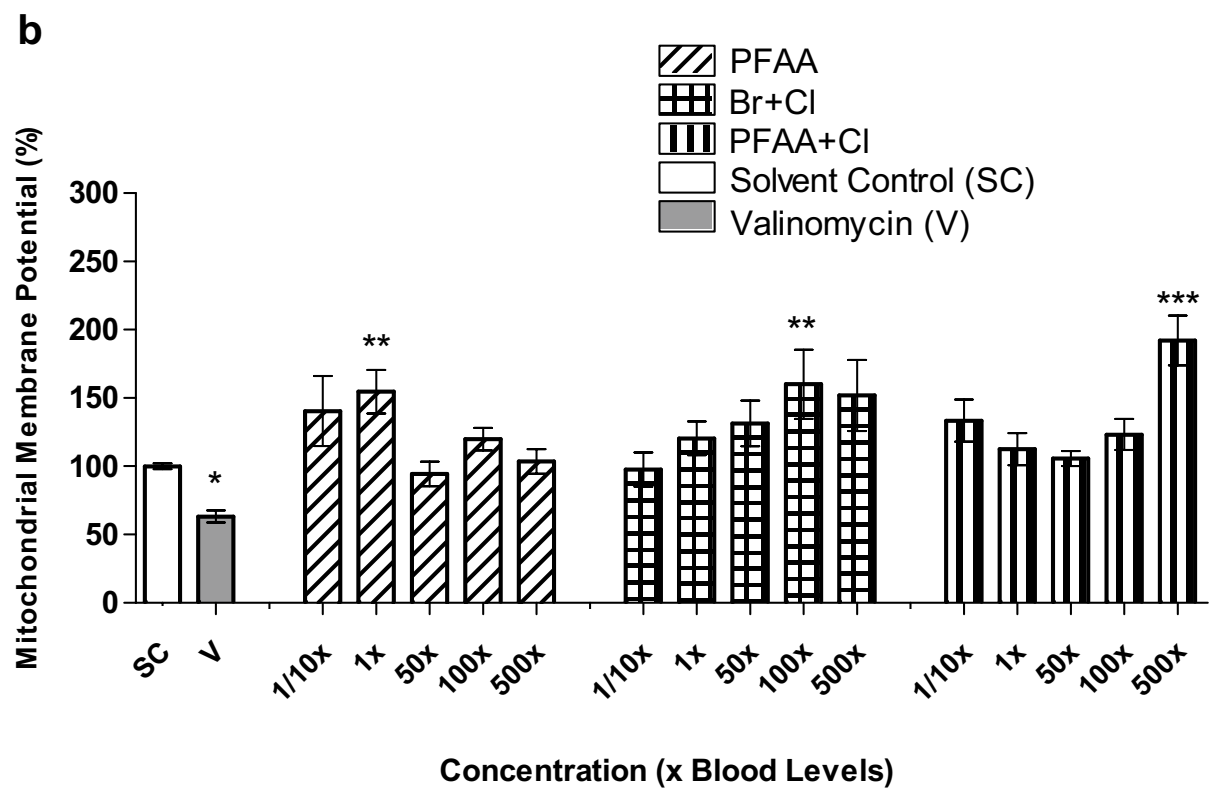

reduction in cell number seen. This effect was not observed for the total POP mixture.

Mitochondrial parameters such as mitochondrial membrane potential (MMP) and mitochondrial mass (MM) are also important indicators of cellular health. For example, apoptosis is an ATP-dependent form of cell death and can be initiated under cellular stress. The process involves the loss of MMP and the release of cytochrome $\mathrm{C}$ from mitochondria through opening of mitochondrial permeability transition pores (AL-Jailawi et al. 2015). This mitochondrial dysfunction results in a decrease in MMP and is expected to correspond with an increase in MM (Gottlieb et al. 2003; Minamikawa et al. 1999). An increase in MM and decrease in MMP were observed for cells treated with valinomycin $(12 \mu \mathrm{M})$ in the present study. This is suggestive of cells entering apoptotic cell death. Mitochondrial swelling upon exposure to valinomycin and uncoupled respiration rates is also observed in corn mitochondria (Hensley and Hanson 1975). Such decreases in MMP and increases in MM have been reported previously in the HepG2 human hepatocarcinoma cell line exposed to POP mixtures identical to those used in the current study. MMP decreased 

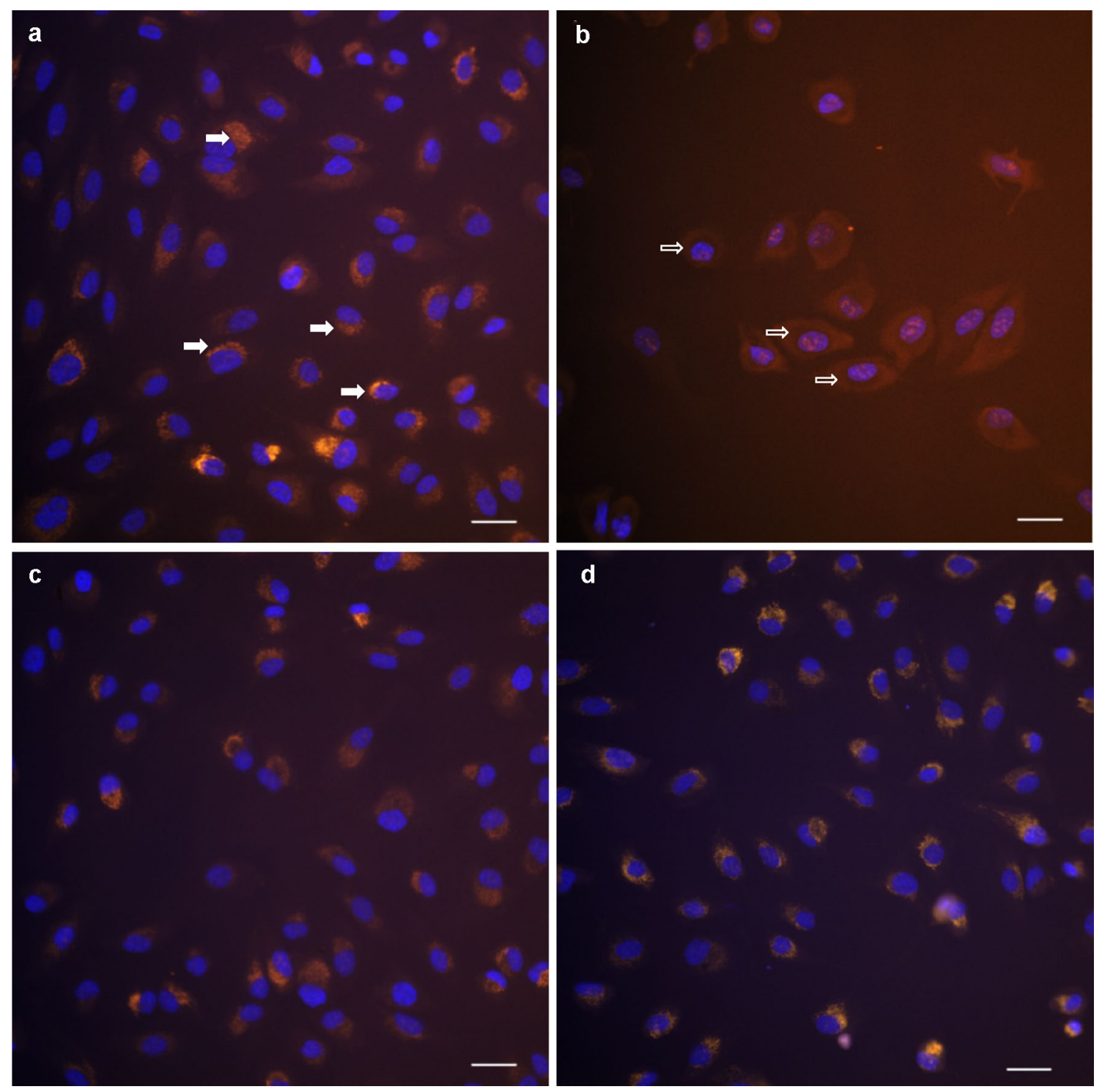

Fig. 5 Example HCA images of the A-498 cells representing changes in mitochondrial membrane potential (MMP) and mitochondrial mass (MM) following $24 \mathrm{~h}$ exposure to a solvent control (0.2\% DMSO), b $12 \mu \mathrm{M}$ valinomycin (PC), $\mathbf{c}$ total mixture $1 \mathrm{x}$ and $\mathbf{d}$ total mixture 500x. Typical HCA images are shown with nuclei (stained by Hoechst 33,342, shown in blue) and mitochondrial structure (stained

significantly after 2 and $48 \mathrm{~h}$ exposure to the PFAA mixture at 5000 and 10,000 blood levels. Short-term exposure $(2 \mathrm{~h})$ to the PFAA $+\mathrm{Br}$ mixture at the highest concentration was found to decrease MMP (Wilson et al. 2016). In contrast, in the present study the exposure of the A-498 kidney cells to the total mixture resulted in an opposite effect with increased MMP, accompanied with decrease in MM. In addition, some of the POP mixture combinations $(\mathrm{Br}+\mathrm{Cl}$ and $\mathrm{PFAA}+\mathrm{Cl})$ had a similar effect which is opposite to the effect of valinomycin. It should be stressed that this occurred at much lower concentrations than those reported for the HepG2 system, by MitoTracker Orange CMTMRos, shown in orange). White block arrows point to examples of cells with intense globular orange staining, representing healthy mitochondria. Open block arrows show a more diffuse staining over a wider area, indicating loss of MMP together with an increase of MM. Images were taken with a $20 \times$ objective magnification, scale bars $=200 \mu \mathrm{M}$

and closer to realistic human exposure levels. A significant increase in MMP and decrease in MM following exposure to total POP mixture could be indicative of an altered mitochondrial metabolism. Increased mitochondrial activity was also observed in human neural stem cells exposed to total mixture (Davidsen et al. 2021).

Taken together this is indicative of a different cytotoxicity mechanism for POPs compared to valinomycin. The opposite mitochondrial changes seen using the total mixture and combinations in HepG2 and A-498 could be due to the different cellular response amongst the two different 


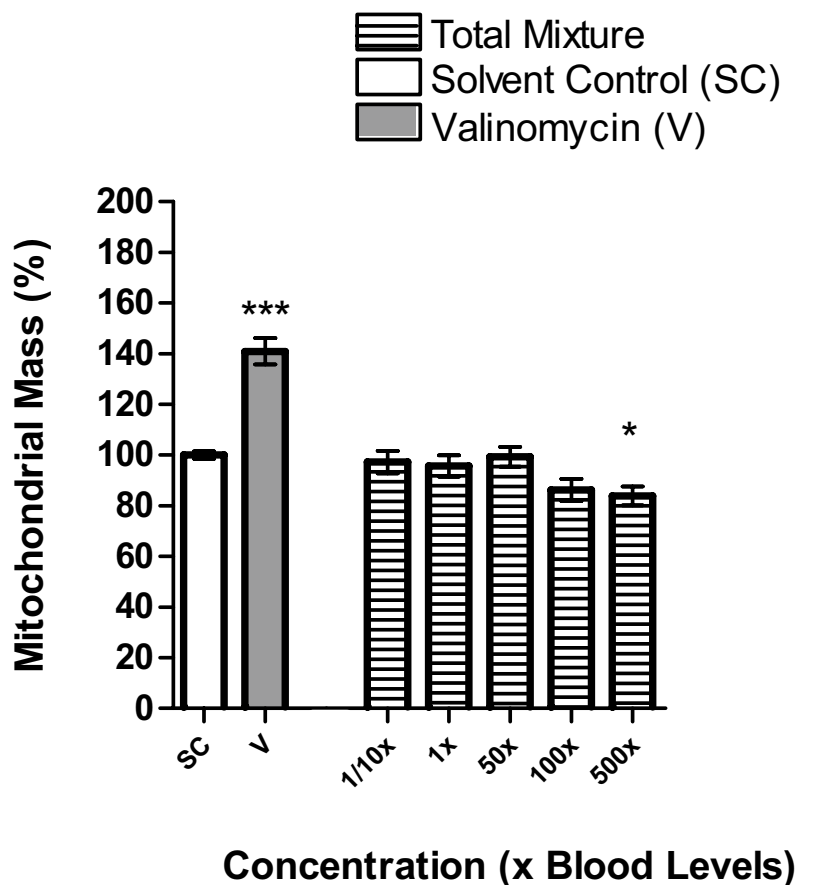

Fig. 6 Mitochondrial Mass (MM) assessed by HCA in the human A-498 cell line following $24 \mathrm{~h}$ exposure to the total mixture. DMSO (0.2\%) was used as solvent control (SC) and valinomycin $(12 \mu \mathrm{M})$ was used as a cytotoxic comparative compound (V). $n=3$; $*=p \leq 0.05, * *=p \leq 0.01, * * *=p \leq 0.001$

cell systems. Alternatively, the A-498 cells might be more resistant to damage induced by the total mixture. For example, the mitochondrial localized apoptosis-inducing factor (AIF) is often down regulated in renal carcinoma cells (Xu et al. 2014); however, no information is available of AIF levels and activity in A- 498 cells. It could also be indicative of POP mixtures acting as oxidative phosphorylation uncoupling agents in the A-498 kidney cell line. Certain chemicals also known as oxidative phosphorylation uncoupling agents can increase the MMP and limit the ROS production by mitochondrial complex 1 (Liu 1997). Cells can sometimes undergo partial mitochondrial uncoupling, leading to decreased ROS production while maintaining sufficient ATP synthesis for delaying cellular senescence (Papa and Skulachev 1997; Brand 2000).

\section{Conclusions}

Exposure to chemical mixtures can effect subtle markers of cellular health in a kidney cell in vitro model. This study highlights the complexity of evaluating the toxic effects of complex chemical mixtures. Surprisingly, the total mixture did not affect cell number and neither did individual chemical classes. However, specific combinations of the PFAA with the $\mathrm{Cl}$ or $\mathrm{Br}$ sub-classes decreased cell number. This demonstrates that interactions of chemical sub-classes may be masked within the total mixture. Thus, understanding how negative effects are elicited by classes of chemical pollutants and their interactions within complex mixtures is crucial for future risk assessment.

Acknowledgements The POP mixtures used in this study were constructed under projects funded by the Norwegian Research Council (NFR), project 213076/H10 and project 204361/H10.

Funding This project has received funding from the European Union's Horizon 2020 research and innovation program under the Marie Skłodowska-Curie Grant Agreement No. 722634 (http://protected.eu. $\mathrm{com} /)$.

\section{Declarations}

Conflict of interest All authors declare that they have no conflict of interest.

Open Access This article is licensed under a Creative Commons Attribution 4.0 International License, which permits use, sharing, adaptation, distribution and reproduction in any medium or format, as long as you give appropriate credit to the original author(s) and the source, provide a link to the Creative Commons licence, and indicate if changes were made. The images or other third party material in this article are included in the article's Creative Commons licence, unless indicated otherwise in a credit line to the material. If material is not included in the article's Creative Commons licence and your intended use is not permitted by statutory regulation or exceeds the permitted use, you will need to obtain permission directly from the copyright holder. To view a copy of this licence, visit http://creativecommons.org/licenses/by/4.0/.

\section{References}

Abdalah R, Wei L, Francis K, Yu SP (2006) Valinomycin-induced apoptosis in Chinese hamster ovary cells. Neurosci Lett 405:6873. https://doi.org/10.1016/j.neulet.2006.06.055

Abraham VC, Towne DL, Waring JF, Warrior U, Burns DJ (2008) Application of a high-content multiparameter cytotoxicity assay to prioritize compounds based on toxicity potential in humans. $\mathbf{J}$ Biomol Screen 13:527-537. https://doi.org/10.1177/1087057108 318428

Adam PJ, Terrett JA, Steers G, Stockwin L, Loader JA, Fletcher GC, Lu L-S, Leach BI, Mason S, Stamps AC, Boyd RS, Pezzella F, Gatter KC, Harris AL (2006) CD70 (TNFSF7) is expressed at high prevalence in renal cell carcinomas and is rapidly internalised on antibody binding. Br J Cancer 95:298-306. https://doi.org/10. 1038/sj.bjc.6603222

Jailawi AL, Nasir MH, Aziz GM (2015) Cytotoxic effect of biosurfactants produced by novel thermophillic Geobacillus thermoleovorans (JQ 912239). Int J Adv Res 3:7

Anderl JL, Redpath S, Ball AJ (2009) A neuronal and astrocyte coculture assay for high content analysis of neurotoxicity. J Vis Exp. https://doi.org/10.3791/1173

Barry V, Winquist A, Steenland K (2013) Perfluorooctanoic Acid (PFOA) exposures and incident cancers among adults living near a chemical plant. Environ Health Perspect 121:1313-1318. https:// doi.org/10.1289/ehp.1306615 
Bergman A, Bergstrand A, Bignert A (2001) Renal lesions in Baltic grey seals (Halichoerus grypus) and ringed seals (Phoca hispida botnica). J Human Environ 30:397-409. https://doi.org/10.1579/ 0044-7447-30.7.397

Berntsen HF, Berg V, Thomsen C, Ropstad E, Zimmer KE (2017) The design of an environmentally relevant mixture of persistent organic pollutants for use in in vivo and in vitro studies. J Toxicol Environ Health A 80:1002-1016. https://doi.org/10.1080/15287 394.2017.1354439

Bortner CD, Cidlowski JA (2002) Apoptotic volume decrease and the incredible shrinking cell. Cell Death Differ 9:1307-1310. https:// doi.org/10.1038/sj.cdd.4401126

Brand MD (2000) Uncoupling to survive? The role of mitochondrial inefficiency in ageing. Exp Gerontol 35:811-820. https://doi.org/ 10.1016/s0531-5565(00)00135-2

Brodaczewska KK, Szczylik C, Fiedorowicz M, Porta C, Czarnecka AM (2016) Choosing the right cell line for renal cell cancer research. Mol Cancer. https://doi.org/10.1186/s12943-016-0565-8

Buchser, W., Collins, M., Garyantes, T., Guha, R., Haney, S., Lemmon, V., Li, Z., Trask, O.J., 2004. Assay Development Guidelines for Image-Based High Content Screening, High Content Analysis and High Content Imaging, in: Sittampalam, G.S., Coussens, N.P., Brimacombe, K., Grossman, A., Arkin, M., Auld, D., Austin, C., Baell, J., Bejcek, B., Chung, T.D.Y., Dahlin, J.L., Devanaryan, V., Foley, T.L., Glicksman, M., Hall, M.D., Hass, J.V., Inglese, J., Iversen, P.W., Kahl, S.D., Kales, S.C., Lal-Nag, M., Li, Z., McGee, J., McManus, O., Riss, T., Trask, O.J., Weidner, J.R., Xia, M., Xu, X. (Eds.), Assay Guidance Manual. Eli Lilly \& Company and the National Center for Advancing Translational Sciences, Bethesda (MD).

Davidsen N, Lauvås AJ, Myhre O, Ropstad E, Carpi D, Gyves EM, Berntsen HF, Dirven H, Paulsen RE, Bal-Price A, Pistollato F (2021) Exposure to human relevant mixtures of halogenated persistent organic pollutants (POPs) alters neurodevelopmental processes in human neural stem cells undergoing differentiation. Reprod Toxicol 100:17-34. https://doi.org/10.1016/j.reprotox. 2020.12.013

Elmore S (2007) Apoptosis: A Review of Programmed Cell Death. Toxicol Pathol 35:495-516. https://doi.org/10.1080/0192623070 1320337

Galluzzi L, Vitale I, Aaronson SA, Abrams JM, Adam D, Agostinis P, Alnemri ES, Altucci L, Amelio I, Andrews DW, Annicchiarico-Petruzzelli M, Antonov AV, Arama E, Baehrecke EH, Barlev NA, Bazan NG, Bernassola F, Bertrand MJM, Bianchi K, Blagosklonny MV, Blomgren K, Borner C, Boya P, Brenner C, Campanella M, Candi E, Carmona-Gutierrez D, Cecconi F, Chan FKM, Chandel NS, Cheng EH, Chipuk JE, Cidlowski JA, Ciechanover A, Cohen GM, Conrad M, Cubillos-Ruiz JR, Czabotar PE, D'Angiolella V, Dawson TM, Dawson VL, De Laurenzi V, De Maria R, Debatin KM, De Berardinis RJ, Deshmukh M, Di Daniele N, Di Virgilio F, Dixit VM, Dixon SJ, Duckett CS, Dynlacht BD, El-Deiry WS, Elrod JW, Fimia GM, Fulda S, GarcíaSáez AJ, Garg AD, Garrido C, Gavathiotis E, Golstein P, Gottlieb E, Green DR, Greene LA, Gronemeyer H, Gross A, Hajnoczky G, Hardwick JM, Harris IS, Hengartner MO, Hetz C, Ichijo H, Jäättelä M, Joseph B, Jost PJ, Juin PP, Kaiser WJ, Karin M, Kaufmann T, Kepp O, Kimchi A, Kitsis RN, Klionsky DJ, Knight RA, Kumar S, Lee SW, Lemasters JJ, Levine B, Linkermann A, Lipton SA, Lockshin RA, López-Otín C, Lowe SW, Luedde T, Lugli E, MacFarlane M, Madeo F, Malewicz M, Malorni W, Manic G, Marine JC, Martin SJ, Martinou JC, Medema JP, Mehlen P, Meier P, Melino S, Miao EA, Molkentin JD, Moll UM, MuñozPinedo C, Nagata S, Nuñez G, Oberst A, Oren M, Overholtzer M, Pagano M, Panaretakis T, Pasparakis M, Penninger JM, Pereira DM, Pervaiz S, Peter ME, Piacentini M, Pinton P, Prehn JHM, Puthalakath H, Rabinovich GA, Rehm M, Rizzuto R, Rodrigues
CMP, Rubinsztein DC, Rudel T, Ryan KM, Sayan E, Scorrano L, Shao F, Shi Y, Silke J, Simon HU, Sistigu A, Stockwell BR, Strasser A, Szabadkai G, Tait SWG, Tang D, Tavernarakis N, Thorburn A, Tsujimoto Y, Turk B, Vanden Berghe T, Vandenabeele P, Vander Heiden MG, Villunger A, Virgin HW, Vousden KH, Vucic D, Wagner EF, Walczak H, Wallach D, Wang Y, Wells JA, Wood W, Yuan J, Zakeri Z, Zhivotovsky B, Zitvogel L, Melino G, Kroemer G (2018) Molecular mechanisms of cell death: recommendations of the Nomenclature Committee on Cell Death 2018. Cell Death Differ 25:486-541. https://doi.org/10.1038/ s41418-017-0012-4

Gottlieb E, Armour SM, Harris MH, Thompson CB (2003) Mitochondrial membrane potential regulates matrix configuration and cytochrome c release during apoptosis. Cell Death Differ 10:709717. https://doi.org/10.1038/sj.cdd.4401231

Grice BA, Nelson RG, Williams DE, Knowler WC, Mason C, Hanson RL, Bullard KM, Pavkov ME (2017) Associations between persistent organic pollutants, type 2 diabetes, diabetic nephropathy and mortality. Occup Environ Med 74:521-527. https://doi.org/ 10.1136/oemed-2016-103948

Haug LS, Salihovic S, Jogsten IE, Thomsen C, van Bavel B, Lindström G, Becher G (2010) Levels in food and beverages and daily intake of perfluorinated compounds in Norway. Chemosphere 80:11371143. https://doi.org/10.1016/j.chemosphere.2010.06.023

Hensley JR, Hanson JB (1975) The action of valinomycin in uncoupling corn mitochondria 1. Plant Physiol 56:13-18

Kataria A, Trachtman H, Malaga-Dieguez L, Trasande L (2015) Association between perfluoroalkyl acids and kidney function in a cross-sectional study of adolescents. Environ Health. https://doi. org/10.1186/s12940-015-0077-9

Knutsen HK, Kvalem HE, Thomsen C, Frøshaug M, Haugen M, Becher G, Alexander J, Meltzer HM (2008) Dietary exposure to brominated flame retardants correlates with male blood levels in a selected group of Norwegians with a wide range of seafood consumption. Mol Nutr Food Res 52:217-227. https://doi.org/ 10.1002/mnfr.200700096

Koponen K, Myers MS, Ritola O, Huuskonen SE, Lindström-Seppä P (2001) Histopathology of feral fish from a PCB-contaminated freshwater lake. Ambio 30:122-126. https://doi.org/10.1579/ 0044-7447-30.3.122

Leonard RC, Kreckmann KH, Sakr CJ, Symons JM (2008) Retrospective cohort mortality study of workers in a polymer production plant including a reference population of regional workers. Ann Epidemiol 18:15-22. https://doi.org/10.1016/j.annepidem. 2007.06.011

Liu SS (1997) Generating, partitioning, targeting and functioning of superoxide in mitochondria. Biosci Rep 17:259-272. https://doi. org/10.1023/a:1027328510931

McComb J, Mills IG, Berntsen HF, Ropstad E, Verhaegen S, Connolly L (2019) Human-Based Exposure Levels of Perfluoroalkyl Acids May Induce Harmful Effects to Health by Disrupting Major Components of Androgen Receptor Signalling In Vitro. Health, Expo. https://doi.org/10.1007/s12403-019-00318-8

Minamikawa T, Williams DA, Bowser DN, Nagley P (1999) Mitochondrial permeability transition and swelling can occur reversibly without inducing cell death in intact human cells. Exp Cell Res 246:26-37. https://doi.org/10.1006/excr.1998.4290

Nicole W (2013) PFOA and cancer in a highly exposed community: new findings from the $\mathrm{c} 8$ science panel. Environ Health Perspect 121:A340. https://doi.org/10.1289/ehp.121-A340

Papa S, Skulachev VP (1997) Reactive oxygen species, mitochondria, apoptosis and aging. Mol Cell Biochem 174:305-319

Pizzorno J (2015) The kidney dysfunction epidemic, part 1: causes. Integr Med Clin J 14:8-13

Polder A, Skaare JU, Skjerve E, Løken KB, Eggesbø M (2009) Levels of chlorinated pesticides and polychlorinated biphenyls in 
Norwegian breast milk (2002-2006), and factors that may predict the level of contamination. Sci Total Environ 407:45844590. https://doi.org/10.1016/j.scitotenv.2009.04.032

Polder A, Thomsen C, Lindström G, Løken KB, Skaare JU (2008) Levels and temporal trends of chlorinated pesticides, polychlorinated biphenyls and brominated flame retardants in individual human breast milk samples from Northern and Southern Norway. Chemosphere 73:14-23. https://doi.org/10.1016/j.chemo sphere.2008.06.002

Steenland K, Woskie S (2012) Cohort mortality study of workers exposed to perfluorooctanoic acid. Am J Epidemiol 176:909917. https://doi.org/10.1093/aje/kws171

Tashla, T., Prodanović, R., Bošković, J., Žuža, M., Soleša, D., Ljubojević, D., Puvača, N., 2018. Persistent Organic Pollutants and Heavy Metals and the Importance of Fish as a Bio-Indicator of Environmental Pollution [WWW Document]. Concepts Dairy Vet. Sci. URL https://lupinepublishers.com/index.php (accessed 7.17.20).

Van Oostdam JC, Dewailly E, Gilman A, Hansen JC, Odland JO, Chashchin V, Berner J, Butler-Walker J, Lagerkvist BJ, Olafsdottir K, Soininen L, Bjerregard P, Klopov V, Weber JP (2004) Circumpolar maternal blood contaminant survey, 1994-1997 organochlorine compounds. Sci Total Environ 330:55-70. https://doi.org/10.1016/j.scitotenv.2004.02.028
Wilson J, Berntsen HF, Zimmer KE, Frizzell C, Verhaegen S, Ropstad E, Connolly L (2016) Effects of defined mixtures of persistent organic pollutants (POPs) on multiple cellular responses in the human hepatocarcinoma cell line, HepG2, using high content analysis screening. Toxicol Appl Pharmacol 294:21-31. https://doi.org/10.1016/j.taap.2016.01.001

Xu JJ, Diaz D, O’Brien PJ (2004) Applications of cytotoxicity assays and pre-lethal mechanistic assays for assessment of human hepatotoxicity potential. Chem Biol Interact 150:115-128. https://doi.org/10.1016/j.cbi.2004.09.011

Xu S, Wu H, Nie H, Yue L, Jiang H, Xiao S, Li Y (2014) AIF Downregulation and Its Interaction with STK3 in Renal Cell Carcinoma. PLoS ONE 9:e100824. https://doi.org/10.1371/journal. pone. 0100824

Youle RJ, van der Bliek AM (2012) Mitochondrial Fission, Fusion, and Stress. Science 337:1062-1065. https://doi.org/10.1126/scien ce. 1219855

Publisher's Note Springer Nature remains neutral with regard to jurisdictional claims in published maps and institutional affiliations. 